\title{
8. Justice, citizenship and methodological de-nationalism
}

\author{
Bridget Anderson
}

\subsection{INTRODUCTION}

In 2002 Andreas Wimmer and Nina Glick Schiller, building on the work of scholars such as Ulrich Beck and John Urry, made a significant contribution to social science in their elaboration of the challenges of 'methodological nationalism'. This naturalises the nation state as a container of social processes and thereby pre-determines and defines certain objects of sociological inquiry, simultaneously removing the nation state form itself from critical inquiry (Wimmer and Glick Schiller 2002). It has important implications for theories and practices of justice, as it prevents us from asking questions such as: what (if any) are the injustices arising from the nation state form itself? How could such injustices be remedied given the crucial role of the state in shaping mechanisms of justice? Or, to respond directly to Wimmer and Glick Schiller's concerns, what would a methodologically de-nationalist approach to justice look like?

In this chapter I will draw on ETHOS research with Roma people to explore how European states have contributed to the construction of racialised minorities, and how the racial hierarchy built into nation states is not only a historical artefact but has major contemporary ramifications. That is, there are indeed injustices baked into the nation state form. Roma people are often legal citizens of a state where they reside, and they may also be European Union (EU) citizens exercising their free movement rights, but the history of European nation state formation has contributed to them being 'minoritised', that is, being turned into a negatively racialised 'minority group'. Attention to their experiences can help us better understand how citizenship is racialised, and how to build connections between 'migrants' and 'citizens'. This, I argue, is a critical first step towards a methodologically de-nationalist approach to justice.

I begin by arguing that the subordination of 'Roma people' is in part a consequence of David Goldberg's 'racial state' and of Europeanisation processes, and that what unites the very different groups that fall under this umbrella 
term is misrecognition (Goldberg 2002). I then touch on the contemporary consequences and expressions in the practices of misrecognition directed against Roma that are imbricated with maldistribution. One state response to racialised misrecognition is to utilise the legal status of citizenship as an equalising mechanism. In the case of the Roma this results in a distinction between national minority Roma and 'migrant' Roma, and in some cases the institutional representation of the former. Yet neither citizenship nor institutional representative mechanisms are sufficient to address the injustices arising from the nation state form, which creates exclusions of 'migrants' and 'national minorities' alike. Following Fraser, the political situation of the Roma could be analysed as a problem of framing (see Chapter 4), but, rather than 'misframing', it might be better seen as illustrating the shortcomings of framing itself. The case of Roma people suggests that we should not assume differences between the 'migrant' and the 'citizen', and not taking such differences as a starting point enables us to see the work that these categorisations do and how 'migrants', 'citizens' and 'Roma' are interconnected. I demonstrate this with reference to mobility and welfare benefits and conclude with a call for theories of justice to problematise the ideal of citizenship, at least in its usual state-embedded form.

I should emphasise that the author is not an expert in Romani Studies and my aim is not to highlight the 'Roma problem'. Hence, I do not give an overview of data that illustrates Roma people's marginalisation, impoverishment and exclusion. Rather I seek to illuminate a European problem by examining the institutional roots of racial misrecognition and misrepresentation, both of which are also related to maldistribution.

\subsection{STATE-MAKING, EUROPE AND THE CONSTRUCTION OF RACIALISED MINORITIES}

As a legal concept, the state is a form of political organisation characterised by a permanent population, a defined territory, a government and a capacity to enter into relations with other states (Crawford 2012). As a socio-political ideal, it is a project that seeks the territorialisation and bordering of political power with a view to producing an intergenerationally enduring 'people' often called the 'nation' (Anderson 1983; Gellner 1983; Breuilly 1993; Stevens 1999; Torpey 2000). Nation-building projects are never complete insofar as the authority of states is constantly challenged by sub-, supra- and transnational organisations and groups (Soysal 1994; Agnew 2005; Beck 2005; Sassen 2006), including those making calls for a different 'nation' or who do not accept territorial boundaries.

A considerable body of sociological, historical, psychological and political theory has highlighted the links between nationalism, xenophobia and racism, 
notably by highlighting how nationalist discourses distinguish between the national 'people' and undesirable 'foreigners' or 'migrants' or citizens who are racialised Others (Reicher and Hopkins 2001; Triandafyllidou 2001; Parekh 2008; Anderson 2013). In his book The Racial State, David Goldberg has argued that race was integral to the emergence of nation states, both conceptually and materially: "At precisely the time rapidly emergent and expanding social mobilities produced increasingly heterogeneous societies globally, social order more locally was challenged to maintain homogeneity increasingly and assertively. The racial state ... is key to understanding the resolution to this modern dilemma' (Goldberg 2002, p. 11). Differences in religion, which had torn apart communities in what is now known as Europe, were internalised and rendered tolerable at the same time as European colonialism contributed to equate difference with 'race'. However, modernity's egalitarian commitments require navigation around ideologies of race and Goldberg distinguishes between racist states such as Apartheid South Africa and racial states which do not rely on theories of 'natural' inferiority but nevertheless are racially configured. While nationalism is concerned with congruence between nation and state, liberal citizenship intervenes to insert legal as well as inherited membership into belonging. Goldberg (2002, p. 266) argues that this does not in fact de-racialise citizenship:

The modernist conception of citizenship, accordingly, has built into it as a constitutive (if not foundational) condition the identification of individual citizen with the state. Implicit in this identification is a triple logic: first, of the disposition to frame citizenship in identity terms; second, of the state taken as a coherent, a singular entity; and by implication third, of citizen-members as settled and more or less statically located within the space of the state.

While the focus of the 'nation' in nation state is on the inclusion of 'the people', the 'racial' in Goldberg's racial state highlights the exclusion of multiple peoples. These exclusions can affect those who hold the legal status of citizenship, such as racialised indigenous groups and other minorities. However, democratic states strive to keep these exclusions apart from matters of race and portray them as linked to migration and citizenship. Indeed, Goldberg argues, the story of modernisation and racial progress depicts a teleology that ends in racelessness, 'rendering invisible the racial sinews of the body politic and modes of rule and regulation' (2002, p. 203).

The current configuration of Roma identities shows how racialisation intersects with histories of state-making and historical and contemporary responses to mobility, exclusion and minoritisation. The term 'Roma' brings together a wide variety of groups with different languages and histories of exclusion and subordinated inclusion. In Turkey distinctions are made by region between the Roma, Dom and Lom. In Austria difference is marked by national minority 
or recently settled status (as well as ethnic affiliations such as Lovara, Sinti and Burgenland-Roma). In the United Kingdom the portmanteau term Gypsy/ Roma/Traveller clearly indicates the composite nature of how the community/ ies is/are understood. In Hungary Roma includes different language groups, the Romungro, Olah and Beás. In the Netherlands the Social Inclusion Monitor explains: 'Roma and Sinti are, like other groups, not homogeneous: various [Roma and Sinti] groups came to the Netherlands at different times, from different countries. The [Roma and Sinti] families differ very much from each other' (MOVISIE 2013, p. 5, cited in Hiah and Knijn 2018, p. 23).

Importantly, the use of the 'Roma' category since the 1990s has largely been driven not by individual states but by European institutions (namely the Council of Europe, the Organization for Security and Co-operation in Europe and the EU) and international bodies such as the Open Society Institute (Vermeesch 2012). Roma-led organisations such as the International Romani Union and the Roma National Congress, supported by international funders, have also played a key role in its diffusion (Nirenbert 2009). The EU funded a number of initiatives to support the Roma during its eastward expansion process (Guy 2009). The Copenhagen criteria outlined the fundamental requirements to be met by candidate countries before they could join the EU, included ensuring 'stability of institutions guaranteeing democracy, the rule of law, human rights and respect for minorities'. ${ }^{1}$ Roma-related issues have also been included in the progress reports submitted by Turkey as part of its EU accession process, allegedly spurring the government to launch the Roma Democratic Opening Process (Akkan 2018). Simhandl (2009) highlights how the discursive shift from 'Gypsies' to Roma was also a shift from characterising these peoples as nomadic and belonging nowhere to discursively settling them in 'Eastern' Europe. This has meant that 'Eastern Roma' could be portrayed as obstacles for 'pre-modern Eastern Europe' to draw level with 'post-modern Western Europe', while rendering the situation in Western Europe itself largely invisible (Simhandl 2009).

The 'Roma' grouping is produced at the intersection of individual statehood and the development and expansion of the EU. However, it is important to recognise that this is against a historical backdrop of brutal and long-running European violence. Diverse groups characterised as Ciganos/Gypsies/Nomads have been persecuted for generations across Europe, partly in the drive to sedentarise and territorialise European populations. This persecution culminated in the Porajmos, or Pharrajimos or Samudaripen, ${ }^{2}$ the Nazi persecution which saw 'Gypsies' stripped of their citizenship, subjected to forced labour and murdered in death camps in their hundreds of thousands. Europe has been slow to acknowledge this anti-Gypsy history. For example, it was only in 1988 that Roma survivors of labour camps in Austria became entitled to state compensation (Meier and Vivona 2018). There continues to be considerable anti-Gypsy 
racism and some measures have Roma peoples as Europe's most negatively perceived minority (Buchanan 2015). Indeed, what the many different peoples covered by the term 'Roma' might be said to have in common is precisely misrecognition, both in the past and today, suggesting a more complex and closer relation between recognition and misrecognition than simple opposites. It is not that, across Europe, there is a united Roma people who are discriminated against, but rather that the defining feature of 'Roma people' is discrimination. The multiple peoples designated as Roma are connected by exclusion more than by shared ethnicity or culture. The term's implications of cultural commonality may appear alien to the diverse array of communities it is meant to designate and it is important to understand criticism of Roma 'disunity' in this context (McGarry 2014).

\subsection{MISRECOGNITION IN PRACTICE}

For all the differences between Roma groups there are three overlapping and common social 'markers', none fixed and all inter-related, that work to categorise people as Roma in their everyday experiences: phenotype, culture and socio-economic marginalisation. The question of how this identity is fixed, how the Roma subject is interpellated and by whom, is critical to experiences of misrecognition, misrepresentation and maldistribution, and it also tells us about the racialised construction of the nation state.

The first social marker is phenotype and more particularly skin pigmentation. This was widely experienced by Roma interviewees as a key marker of their identity and it is reflected in the discourse. In Turkey, for example, the Roma are called esmer vatandas or 'dark-skinned citizens' (Akkan 2018). In the United Kingdom, Roma who saw themselves as having darker skin were pleased that super-diverse contexts enabled them to 'pass' as 'Indian' or 'Turkish' (Anderson et al. 2018). The second marker, 'culture', is imbricated with the first marker of 'race'. In European discourse there has been a significant shift away from biological racism towards markers of ethnic and cultural difference (Balibar 1991). Certain kinds of racist expression, such as pseudo-scientific associations of non-white phenotypes with lower intelligence (Banton 1998), have been de-legitimised, but racism has rarely worked solely through skin colour and long drawn on markers of culture and disposition. The shared history signalled by ethnicity/culture, like race, is usually imagined and claimed through ancestry, and both Hungary and Austria have an ancestral requirement for official recognition of 'national minorities'. In addition, minority and racialised cultures are often associated with tradition and backwardness, for instance through infantilising representations of 'joyous' music playing country folk, who sometimes indulge in picaresque 'naughtiness' (Araújo and Brito 2018; Hiah and Knijn 2018). A broader under- 
standing of culture as way of life and social positioning suggests that 'Roma culture' more generally can be depicted as anti-social behaviour. A Dutch academic inadvertently captured this when trying to explain the social context of hostility to Roma:

I also wouldn't want to live next to someone like that ... a Roma family who ... celebrated finding a house and invited three quarters of their family. The whole street was full of cars. In the evening a pig is slaughtered in the backyard that makes a lot of noise ... all those children hanging out of the window looking at how the pig is treated. We can't have that can we? Or women crying rushing out of their house because they are being chased by their husbands, we can't have that either, right? (Hiah and Knijn 2018, p. 29)

As the quote suggests, while ancestry is emphasised in ethnicity claims, family receives greater emphasis in conversations about culture. A common trope in representations of minority cultures is that they are exceptionally prone to violate human rights and oppress women. In an instantiation of what Spivak (1988) calls 'White men saving brown women from brown men', Roma men are often described as perpetrators of domestic violence, forced marriages and other crimes. In contrast to the sexism of dominant cultural groups which is acknowledged as complex and context dependent, that of minority cultures is simply attached to 'tradition' and detached from broader social structures. The racialising gaze claims objectivity and fails to see its power:

We do not look away from the Roma background. When I am sitting in front of you [the interviewer was a person of colour raised in the Netherlands and speaking perfect Dutch] I see that you are neither Roma nor Dutch, that's fine ... I do not have to do anything with that, but I save this information. I also do not have to be completely blank. And that goes for dealing with Roma. That you can take note of the fact, 'Hey that is a Roma' ... then look into the problem. (Hiah and Knijn 2018, p. 30)

The third social marker of Roma identity is their marginalised socio-economic status. Roma identity is extremely difficult to disentangle from socio-economic factors. Poverty is focused on by policymakers, media, academics and some activists, all with very different intentions. It is bound up with perceptions of a 'culture of deprivation' (Anderson et al. 2018) or 'poverty' (Zemandl 2018) and is often related to attempts to 'responsibilise' people or train them away from deviance, or indeed remove them from settlements or states (Cahn and Vermeersch 2000; Nacu 2012). The association of Roma with ignorance, criminality, laziness and cunning is such that, when Roma are not poor, this too is suspicious (Araújo and Brito 2018). The case studies indicate that at the national level Roma/Gypsies are often synonymous with vulnerable socio-economic groups and phrases like 'multiply disadvantaged child' (Zemandl 2018) or 
'multi-problem families' (Hiah and Knijn 2018) are scarcely coded ways of referring to Roma people. The Roma themselves demand redistributive justice but at the same time are critical of "class reductionism or ... excess of paternalism' (Araújo and Brito 2018, p. 25) which offer a truncated picture of their lives, especially when marginal socio-economic status is stigmatised not simply as a description of one's earnings or living conditions, but also as a matter of 'culture'.

Given the considerable evidence of Roma people across Europe being subject to racist abuse and violence including from the police, it should come as no surprise that many 'Roma' seek to avoid being categorised as such. 'Roma' is now widely used in policy and activist circles, but this dissemination is relatively recent and it is probably fair to say that widespread Roma self-identification currently constitutes more of a project than a reality. For some, it is a move away from pejorative stereotypes often summoned by words like 'Ciganos', 'Cigany' and 'Gypsy': in Austria, the 'Roma' national minority was thus named in part because the word means 'person' in Romanes (Meier and Vivona 2018). For others, it is a term imposed from above that has little daily resonance: 'its use is a symptom of spastic ... political correctness' (Zemandl 2018, p. 12). Those who use the term 'Roma' can find it has little traction on the ground:

I worked in Tyrol for a while and there I said that I am a Roma woman and they asked, 'What does that mean?'. Then I told them, 'Well, a Gypsy ...' 'Right, right, of course.' Of course, then you face the first stereotypes. But it was okay for me because we started to discuss them. (Meier and Vivona 2018, p. 27)

The imperfect correspondence between internal and external adscriptions of Roma identity raises the question of whether sometimes Roma labelling itself may be a form of symbolic violence or misrecognition, especially when the label is systematically used to offer statistical evidence of disadvantage and marginalisation (Gatti et al. 2016).

\subsection{MAKING THE DIFFERENCE: A QUESTION OF CITIZENSHIP}

The category of 'Roma' compares and overlaps with others like the 'EU citizen' and the 'Third Country National'. Indeed, the repeated association of Roma with a range of social problems which blur socio-economic location, phenotype and culture parallels the ways in which 'migrants' are imagined as poor, negatively racialised and having a backward 'culture'. As noted in previous sections, democratic states strive to portray themselves as 'raceless', and the legal and apparently equalising status of citizenship is a key mechanism for 
enabling this. All legal citizens are supposed to be equal regardless of race/ethnicity, and in many states there are legal and policy measures in place to ensure that social or institutional practices that fail to recognise this are prohibited as discriminatory. However, its dominance in defining the scope of justice makes citizenship, as legal or socio-cultural relation, a critical 'faultline' of justice (see also Chapter 14). Who sheds and who retains their 'migrant' status is bound up with nationally specific ways of encoding race. Consider the phrase 'second generation migrant' or 'person of migrant background', terms which may be applied to people who have not crossed a state border in their lives. It signals that it is possible to be at once a 'migrant' and a legal 'citizen', but notably such terms in Europe are rarely applied to the descendants of white immigrants. It is too easy to dismiss this as simply because of public ignorance given that such terms are actively institutionalised by several European states. If the development of the modern state 'depended on the ideological work of manufacturing sameness' and the nationalising logic of sameness derives from a conceptualisation of 'race' within Europe and in Europe's colonies, we should not be surprised that racialised differentiations can be highly salient in popular representations of 'the migrant', overriding legal status or other forms of belonging (Anderson 2013).

The category of Roma exposes how racialisation and mobility controls are connected, and how state bordering constructs the distinction between indigenous people, national minorities and immigrants. In Turkey before World War II 'itinerant Gypsies' were explicitly linked to immigrants (Akkan 2018). In the contemporary United Kingdom, which hosts a considerable number of EU citizens from post-2004 accession states, 'Roma' are associated with 'migrants', and Roma policy must be understood within the paradigm of migration control as much as the paradigm of ethnic minorities and anti-racism. Despite the institutionalisation of differences between 'Roma' and 'Gypsy' in some cases practices of mobility and protest look to be joining up the Eastern 'Roma' and the Western 'Gypsy' (Anderson et al. 2018). However, while 'migrants' may be legitimately excluded from the democratic nation without invoking race or ethnicity because they are not citizens, those Roma who have citizenship and thereby stand in a legal relationship of equality with other citizens must be included.

There are two interconnected mechanisms for placing Roma within nationalising logics. The first is to distinguish Roma 'migrants' from 'national' Roma, and the second is to institutionalise the representation of the latter as a constitutive community within the state. For minority groups to constitute national minorities both Austria and Hungary require ancestral residence. In Hungary Article 1.2 of the 1993 Ethnic Group Act required minorities to have 'lived on the territory of Hungary for at least a century'. The Austrian Ethnic Group Act also had a strongly territorial understanding of minority, and 
national minorities were defined as Austrian nationals 'living and residing in parts of the federal territory whose mother tongue is not German and who have their own traditions and folklore'. ${ }^{3}$ According to legal practice, recognition requires continuity of residence for three generations or 90 years; residence, home and rootedness in Austria or Beheimatung; and Austrian citizenship (Jurić-Pahor 2009). Roma peoples' alleged lack of attachment to territory meant the authorities were reluctant to grant them national minority status for many years (Meier and Vivona 2018).

Other states too seek to distinguish between migrants and 'their' Roma/ Gypsies/Sinti (the term itself can be instrumental to making the distinction). Portugal and the Netherlands both make strong claims to being 'raceless' in Goldberg's sense of the word. The official narrative of the Portuguese state has been that the country is 'race blind' and until recently ethnically homogeneous (Araújo and Brito 2018). In both states the official stance is that specific representative mechanisms would 'discriminate' against ethnic minorities. In the Netherlands this alleged neutrality marked a shift as for many years, under the model of pillarisation, minority policies financed associations representing minority groups. From 2010, criticism of minority inclusion policies (associated with labelling and stigmatisation) led to their abolition and to a policy shift towards 'problematic social categories' (Hiah and Knijn 2018). While the language of autochthony has been repudiated, when Roma/Sinti families date their arrival in the Netherlands is highly relevant to their status and to their position vis-à-vis social inclusion policies (Hiah and Knijn 2018). Through distinguishing between Roma as national minorities and Roma as migrants the relation between the national and the racial state can be obfuscated and the citizenship relation cast as non-racial, but national minorities are also racialised, and under political pressure these distinctions can break down. For example, in June 2018 the Italian Interior Minister Matteo Salvini undertook to expel non-Italian Roma people from Italy and said, in an interview with the television station Telelombardia on 18 June 2018: 'Unfortunately we will have to keep the Italian Roma because we can't expel them.' Given how states institutionalise citizenship as a crucial vector of difference, they can hardly be described as 'honest brokers' in providing redress against this kind of racial injustice.

In recent decades, efforts have been made to embed the representation of Roma as national minorities by putting in place specific institutions or representative mechanisms. In Hungary, for example, the Minority Rights Act 1993 guaranteed both individual and collective minority rights and statutorily recognised the Roma and 12 other named groups 'as national or ethnic minorities'. These national minorities were given the right to establish local, regional and national minority self-governments (MSGs). However, despite their title the authority of MSGs is limited to issues framed around protection of traditions 
and culture, with no power to address socio-economic issues. In a damning assessment following attempted reforms the Organization for Security and Co-operation in Europe found that 'the MSGs tend to marginalise Romani issues by depositing them in a parallel, fairly powerless, quasi-governmental structure rather than addressing them through established governing bodies' (OSCE/ODIHR 2006, p. 6). As one interviewee in Hungary put it: 'We are not ahead, no matter whether the government interferes or someone else. Everybody is only interested in their own interests and not looking at what could be good for us, only their own interests ... Official political institutions hide behind the law' (Zemandl 2018, pp. 47-8). There is a similar disenchantment in Austria where the Ethnic Group Act 1979 attempted to institutionalise dialogue with minority groups and where Ethnic Advisory Councils represent autochthonous Roma who have been resident for three generations. Yet still there is a sense, as one Roma interviewee asserted, that 'politics is made by others' (Meier and Vivona 2018).

\subsection{REPRESENTATION AND FRAMING}

Fraser's identification of representation as key to justice suggests a methodologically de-nationalist approach as she comes to it via a critique of what she calls the Keynsian-Westphalian frame of modern territorial states and the assumed scope of justice as the citizenry: 'Faced with global warming, the spread of AIDS, international terrorism and superpower unilateralism, many believe that their chances for living good lives depend at least as much on processes that trespass the borders of territorial states as on those contained within them' (Fraser 2005a, p. 304). Misrepresentation concerns 'the scope of the state's jurisdiction and the decision rules by which it structures contestation'. In other words, it encompasses the boundary-setting of the political community (the criteria used to distinguish members from non-members) and the 'terms on which those included in the political community air their claims and adjudicate their disputes' (2005b, p. 81). Fraser (2009) identifies two kinds of misrepresentation. She labels 'misframing' the form of misrepresentation that arises when a community's boundaries wrongly exclude some people from 'authorised contests over justice' and distinguishes it from the injustice of 'ordinary-political misrepresentation' or exclusion from political decision-making within the nation state paradigm. People may be unjustly excluded from the political community because the boundaries themselves have been unjustly drawn (see also Chapter 14).

The minority institutions described above can be characterised as attempts at what Nancy Fraser would term 'ordinary political representation'. However, ordinary political representation seems hard to achieve given the racial state and the fact that institutional representation is not seen as appropriate for 
migrants or those Roma who do not have formal citizenship. More fundamentally, representation in territorial institutions appears to be at odds with a population that makes no territorial claims and whose multifarious identities are united by exclusion. It is not simply that Roma lack a political consciousness, but that most do not lay claim to a particular territory that materially affects to gather together nation and state. Some Roma aspire to be 'citizens without frontiers' (Isin 2012) but, like that of (other) migrants and (other) racialised groups, their representation remains trapped in the forced sedentariness of the national frame.

In the past one response to Roma exclusion was a brief attempt at Roma nationalism. However, I have already noted the heterogeneity of Roma identity, and the elaboration of Roma nationalism has become an elite-driven process and thus it is possible that ordinary Roma have no clear understanding of what Roma nationalism actually is (McGarry 2009). The suggestion that there is a need to inculcate Roma nationalism seems rather bizarre in a European context where nationalist sentiment is often seen as a problem and the general trend is to encourage the de-nationalisation of political claims.

Fraser argues that the national framing of claims for justice is limiting and the territorial state cannot accommodate many justice claims. Is it then more appropriate to analyse the Roma, like migrants, through the lens of misframing? While political justice is often understood as requiring inclusion into territorial states, perhaps we need to problematise the scale of membership and, therefore, representation. European institutions have attempted to insist that all levels of government share a responsibility for inclusion (Agarin 2014). But what exactly is understood by 'government', and how can fair representation be achieved at all relevant levels? One interesting issue is the relationship that should exist between Roma representatives in different institutions and organisations. Should European representatives be chosen by those working at smaller scales or should they be directly accountable to individual Roma? In the former case, should they only be chosen by representatives who explicitly identify as Roma or also by other groups which are lumped under this label in institutional discourse? The Roma are so heterogeneous, even within one state, that their umbrella grouping is clearly an artefact of European institutions and other powerful stakeholders. So, what does it mean to be included in this umbrella group, rather than recognised as, for example, Rom or Dom?

Attention to the situation of migrants and Roma suggests that the problem is not only misframing but framing itself. As Muldoon (2012) notes, 'To suggest, as [Fraser] does on many occasions, that the Westphalian system "gerrymanders political space" or "partitions political space along territorial lines" is to presume that the whole world is already a political space with moveable internal boundaries' (p. 637). The experience of migrants and Roma, citizens and non-citizens, suggests that the racialising fixing in place is itself 
a source of injustice. For example, in the Netherlands the Roma are categorised along with Sinti and Traveller groups as people living in mobile homes or Woonwagenbewoners. The Dutch Caravan Act 1968, passed at the apogee of the Keynesian-Westphalian state, aimed to 'normalise' and 'integrate' Roma communities and deprived many people of trades which relied on them being mobile (Hiah and Knijn 2018). Rather than reframing alone, we need to think more carefully about mobility, states and justice, returning us to the challenge of methodological nationalism.

\subsection{METHODOLOGICAL DE-NATIONALISM AND JUSTICE: MISFRAMING AND MOBILITY}

A methodologically de-nationalist approach to justice does not assume legal citizenship in a state as a condition for equality. It therefore does not assume a distinction between 'migrant' and 'citizen'. Like 'migrant' and 'Roma', 'citizen' is both a juridical and a social subject and citizenship theories have delved deeply into the distinction and relation between citizenship as a legal status with associated rights and citizenship as belonging and connection (Benhabib 2004; Hindess 2004; Bosniak 2006; Bauböck and Guiraudon 2009; Shachar 2009; Carens 2013). The case of Roma people exemplifies the constructed nature of 'migrant' and 'citizen' as states struggle to differentiate between 'their' Roma and Others, but also illuminates how some legal citizens can be stripped from the rights of citizenship by virtue of their perceived foreignness.

Roma citizens are not recognised as 'belonging' to the nation, or only belong in an exceptional way (Anderson and Dupont 2018). They are often singled out as not having the right values, as being members of a group that may be legal citizens, but do not have the values of the citizen. For example, in ETHOS research on social assistance, all national studies found that Roma people were singled out by non-Roma claimants, and in some cases by client managers, as being predisposed to fraud and laziness (Anderson and Dupont 2019). It is not only Roma who are stigmatised for claiming certain kinds of welfare benefits (Anderson and Dupont 2019). The rights of the welfare state have been described as the pinnacle of the achievements of citizenship, enabling 'social citizenship' (Marshall 1950), yet in a vicious circle those who claim benefits are stigmatised, and those who are racialised, poor or otherwise marginalised are not believed to be eligible for benefits.

The relation between governing and sedentariness does not only shape the experiences of migrants and the Roma. The Roma people who, as EU citizens, cannot be removed under immigration controls are finding that homelessness policies are being mobilised to displace them instead (Fekete 2018), but more generally across Europe rough sleeping can result in expulsion. If one is 
a citizen this may be expulsion from a neighbourhood, city or region; if one does not have legal status it may be from a country. While mobility regimes for citizens are typically governed at the local rather than national state level, anti-begging legislation is also being used by many European states to restrict the mobility of unwanted populations. Even before the development of European welfare states, poor relief was often limited to parish residents. The poor were liable to be 'moved on' if there was any suggestion that they might become unemployed, stay long enough to make a claim on the parish, or have a baby that would be born in the parish and therefore become the parish's responsibility (Anderson 2014). In a move that is highly reminiscent of old poor laws, access to the welfare state has replaced the levers of immigration controls in efforts to control the mobility of certain EU citizens (Shutes 2016). To deter people who do not have the resources to support themselves, complex restrictions are imposed on access to certain non-contributory benefits. Returning nationals are not exempt from these restrictions: they may be legal citizens, but they are no longer local residents.

Not assuming difference between 'migrant' and 'citizen' enables us to find similarities between them. Citizens do not always have to have reside outside the national territory to find themselves turned into migrants. In some areas of the United Kingdom citizens who cross a local authority boundary and claim social housing are also referred to as 'migrants'. They are subject to the kinds of complaints that are more customarily levelled against international migrants: taking housing away from locals, coming to take advantage of the welfare state, committing crimes, bringing drugs and so on. To deserve to get onto the waiting list for social housing in many local authorities, not only is there a minimum period of residence (sometimes as long as ten years) but also an effective 'good character' requirement, demonstrated through volunteering, going to the gym, even stopping smoking (Carter 2015). That is, these internally mobile citizens are effectively turned into migrants and must find a means of recovering their status in ways that parallel the requirements put on naturalising migrants.

Internal mobility for the purposes of accessing the welfare state more generally is frowned upon. In the Netherlands social assistance claimants can be sanctioned for a month's worth of benefit if they move without a 'clear and good reason' (Knijn and Hiah 2019). In Turkey some recipients of disability and elderly allowance cannot even move to a different street in the same district. Any application is immediately terminated and treated as a new application, as a result of which the benefit is withdrawn for months (Akkan and Serim 2019). In Hungary social housing claimants have to be able to prove residence for a year in a local area (Veres 2019), while in Portugal claimants can be required to check in at the parish council every two weeks in order to confirm unemployment status (Brito 2019). Social assistance claimants often 
have little choice about where they live and indeed can often effectively be forced to move. One British young mother described how she was moved to cheaper accommodation: 'They dumped me, basically. I didn't know where the shops were. It was in the middle of nowhere. The closest GP [General Practitioner] was 40-minutes' walk. The closest shop was about 20-minutes' walk' (Dupont et al. 2019, p. 40). In Turkey for the parents of disabled children to be able to claim social assistance, they must take their child to hospital to receive a medical report and return there every one to three years. This requirement is extremely onerous for some who do not necessarily have access to the appropriate transport and for whom getting out of the house is very difficult (Akkan and Serim 2019). At the same time as residence must be settled, claimants can be required to travel long distances to work. In Austria applicants must be prepared to make a two-hour one-way commute, and longer if they live in a remote area. This commuting requirement was felt to be unfair:

If that's the worst job you can imagine you also need to ask whether it's justified to commute in the first place. Then it also depends on my resources, my environment and so on. If I have five children to care for and then also need to commute, then the situation becomes critical. (Meier and Tiefenbacher 2019, p. 43)

\subsection{CONCLUSION: RE-SCOPING JUSTICE}

Attention to the experiences of the Roma can help inform a methodologically de-nationalist approach to justice. This problematises the legal status of citizenship insofar as it is implicated in racial misrecognition as well as in the political and economic marginalisation of those constructed as migrants and national minorities. The historical and contemporary experiences of people now categorised as Roma also illustrate the importance of mobility for redistribution, recognition and representation. The issues arising from the tension between nationalism and the freedom to move are fundamental to justice and are not confined to Roma but raise questions for all of us.

\section{NOTES}

1. Presidency conclusions of the Copenhagen European Council, 21-22 June 1993, accessed 23 March 2020 at http://www.europarl.europa.eu/enlargement/ec/cop en.htm.

2. Porajmos means 'devouring', Pharrajimos, 'fragmentation or destruction' and Samudaripen, 'mass killing'.

3. Volksgruppengesetz - Bundesgesetz über die Rechtsstellung der Volksgruppen in Österreich, BGB1. Nr. 396/1976, last amended by BGB1. I Nr. 84/2013, Art 1 (2). 


\section{REFERENCES}

Agarin, Timofey (2014), 'Travelling without moving? Limits of European governance for Romani inclusion', Ethnicities, 14 (6), 737-55.

Agnew, John (2005), 'Sovereignty regimes: Territoriality and state authority in contemporary world politics', Annals of the Association of American Geographers, 95 (2), 437-61.

Akkan, Başak (2018), 'Roma and representative justice in Turkey', ETHOS country report for ETHOS report D5.2, accessed 24 March 2020 at https://ethos-europe.eu.

Akkan, Başak and Simla Serim (2019), 'Care allowance as a social assistance scheme in Turkey: Deservingness, mobility and just welfare state', ETHOS country report for ETHOS report D5.5, accessed 24 March 2020 at https://ethos-europe.eu.

Anderson, Benedict (1983), Imagined Communities: Reflections on the Origin and Spread of Nationalism, London: Verso Books.

Anderson, Bridget (2013), Us and Them? The Dangerous Politics of Immigration Controls, Oxford: Oxford University Press.

Anderson, Bridget (2014), 'Precarious pasts, precarious futures', in Cathryn Costello and Mark Freedland (eds), Migrants at Work: Immigration and Vulnerability in Labour Law, Oxford: Oxford University Press, pp. 29-43.

Anderson, Bridget and Pier-Luc Dupont (2018), 'How does it feel to be a problem? What we can learn about justice as political representation from empirical case studies', ETHOS report D5.2, accessed 24 March at https://ethos-europe.eu/.

Anderson, Bridget and Pier-Luc Dupont (2019), 'Just deserts? Justice, deservingness and social assistance', ETHOS report D5.5, accessed 24 March at https://www.ethos -europe.eu/.

Anderson, Bridget, Dora-Olivia Vicol, Pier-Luc Dupont and Julia Morris (2018), 'Political representation and experienced recognition among Roma in the UK', ETHOS country report for ETHOS report D5.2, accessed 24 March 2020 at https:// www.ethos-europe.eu/.

Araújo, Sara and Laura Brito (2018), 'Tensions between institutionalised political justice and experienced (mis)recognition: Portuguese case study on the experiences of Roma communities', ETHOS country report for ETHOS report D5.2, accessed 24 March 2020 at https://www.ethos-europe.eu/.

Balibar, Etienne (1991), 'Is there a neo-racism?', in Etienne Balibar and Immanuel Wallerstein (eds), Race, Nation, Class: Ambiguous Identities, London: Verso, pp. 17-28.

Banton, Michael (1998), Racial Theories, Cambridge: Cambridge University Press.

Bauböck, Rainer and Virginie Guiraudon (2009), 'Introduction. Realignments of citizenship: Reassessing rights in the age of plural memberships and multi-level governance', Citizenship Studies, 13 (5), 439-50.

Beck, Ulrich (2005), Power in the Global Age: A New Global Political Economy, Cambridge: Polity Press.

Benhabib, Seyla (2004), The Rights of Others: Aliens, Residents and Citizens, Cambridge: Cambridge University Press.

Bosniak, Linda (2006), The Citizen and the Alien: Dilemmas of Contemporary Membership, Princeton, NJ: Princeton University Press.

Breuilly, John (1993), Nationalism and the State, Chicago, IL: University of Chicago Press. 
Brito, Laura (2019), 'Social justice and the Portuguese welfare state', ETHOS country report for ETHOS report D5.5, accessed 24 March 2020 at https://www.ethos -europe.eu/.

Buchanan, Rose (2015), 'Roma Gypsies most negatively perceived European minority group, survey finds', The Independent, 19 November, accessed 24 March 2020 at https:/www.independent.co.uk/news/world/europe/roma-gypsies-most-negatively -perceived-european-minority-group-survey-finds-a6740746.html.

Cahn, Claude and Peter Vermeersch (2000), 'The group expulsion of Slovak Roma by the Belgian government: A case study of the treatment of Romani refugees in western countries', Cambridge Review of International Affairs, 13 (2), 71-82.

Carens, Joseph (2013), The Ethics of Immigration, Oxford: Oxford University Press.

Carter, Rosie (2015), 'Borders, boundaries and barriers: Housing and migration in the UK', Dissertation for MSc in Migration Studies, University of Oxford.

Crawford, James (2012), Brownlie's Principles of Public International Law (8th edn), Oxford: Oxford University Press.

Dupont, Pier-Luc, Bridget Anderson and Dora-Olivia Vicol (2019), 'Working for benefits: Deservingness and discrimination in the British social security system', ETHOS country report for ETHOS report D5.5, accessed 24 March 2020 at https:// ethos-europe.eu/.

Fekete, Liz (2018), Europe's Fault Lines: Racism and the Rise of the Right, London: Verso Books.

Fraser, Nancy (2005a), 'Mapping the feminist imagination: From redistribution to recognition to representation', Constellations, 12 (3), 295-307.

Fraser, Nancy (2005b), 'Reframing justice in a globalizing world', New Left Review, 36, 69-88.

Fraser, Nancy (2009), Scales of Justice: Reimagining Political Space in a Globalizing World, New York: Columbia University Press.

Gatti, Roberta, Sandor Karacsony, Kosuke Anan, Celine Ferre and Carmen De Paz Nieves (2016), Being Fair, Faring Better. Promoting Equality of Opportunity for Marginalized Roma, Washington, DC: World Bank Group.

Gellner, Ernest (1983), Nations and Nationalism, Oxford: Blackwell.

Goldberg, David (2002), The Racial State, Oxford: Blackwell.

Guy, Will (2009), 'EU initiatives on Roma: Limitations and ways forward', in Nando Sigona and Nidhi Trehan (eds), Romani Politics in Contemporary Europe: Poverty, Ethnic Mobilization, and the Neoliberal Order, New York: Palgrave Macmillan, pp. 23-50.

Hiah, Jing and Trudie Knijn (2018), 'Country report on the current and historical minoritization of Roma minorities in the Netherlands', ETHOS country report for ETHOS report D5.2, accessed 24 March 2020 at https://www.ethos-europe.eu/.

Hindess, Barry (2004), 'Citizenship for all', Citizenship Studies, 8 (3), 305-15.

Isin, Engin (2012), Citizens Without Frontiers, New York: Bloomsbury.

Jurić-Pahor, Marija (2009), 'Hidden identities within national minority groups: The case of Slovenes in Carinthia and in the province of Trieste', in Christian Promitzer, Klaus-Jürgen Hermanik and Eduard Staudinger (eds), (Hidden) Minorities: Language and Ethnic Identity between Central Europe and the Balkans, Berlin: Lit Verlag, pp. 35-58.

Knijn, Trudie and Jing Hiah (2019), 'Coping with the Participation Act: Welfare experiences in the Netherlands', ETHOS country report for ETHOS report D5.5, accessed 24 March 2020 at https://www.ethos-europe.eu/. 
Marshall, Thomas Humphrey (1950), 'Citizenship and social class', in Thomas Humphrey Marshall and Tom Bottomore (eds), Citizenship and Social Class, London: Pluto Press, pp. 30-9.

McGarry, Aidan (2009), 'Ambiguous nationalism? Explaining the parliamentary under-representation of Roma in Hungary and Romania', Romani Studies, 19 (2), $103-24$.

McGarry, Aidan (2014), 'Roma as a political identity: Exploring representations of Roma in Europe', Ethnicities, 14 (6), 756-74.

Meier, Irene and Wanda Tiefenbacher (2019), 'From social assistance to minimum benefits and back: Retrenchment of the welfare state in Austria, consequences, and ideas about justice', ETHOS country report for ETHOS report D5.5, accessed 24 March 2020 at https://ethos-europe.eu/.

Meier, Irene and Maddalena Vivona (2018), 'The tension between institutionalised political justice in Austria and Roma's experienced (mis)recognition', ETHOS country report for ETHOS report D5.2, accessed 24 March 2020 at https:/ethos -europe.eu/.

MOVISIE (2013), Monitor Inclusie: nulmeting, Utrecht: Movisie.

Muldoon, Paul (2012), 'The injustice of territoriality', Critical Review of International Social and Political Philosophy, 15 (5), 631-48.

Nacu, Alexandra (2012), 'From silent marginality to spotlight scapegoating? A brief case study of France's policy towards the Roma', Journal of Ethnic and Migration Studies, 38 (8), 1323-8.

Nirenbert, Julius (2009), 'Romani political mobilization from the First International Romani Union Congress to the European Roma, Sinti and Traveller Forum', in Nando Sigona and Nidhi Trehan (eds), Romani Politics in Contemporary Europe: Poverty, Ethnic Mobilisation, and the Neoliberal Order, Basingstoke: Palgrave Macmillan, pp. 94-115.

OSCE/ODIHR (2006), 'The Hungarian minority self-government system as a means of increasing Romani political participation', accessed 24 March 2020 at https://www .osce.org/odihr/25974?download=true.

Parekh, Bhikhu (2008), A New Politics of Identity: Political Principles for an Interdependent World, Basingstoke: Palgrave Macmillan.

Reicher, Steve and Nick Hopkins (2001), Self and Nation: Categorization, Contestation and Mobilization, London: Sage.

Sassen, Saskia (2006), Territory, Authority, Rights: From Medieval to Global Assemblages, Princeton, NJ: Princeton University Press.

Shachar, Aylet (2009), The Birthright Lottery: Citizenship and Global Inequality, Cambridge, MA: Harvard University Press.

Shutes, Isabel (2016), 'Work-related conditionality and the access to social benefits of national citizens, EU and non-EU citizens', Journal of Social Policy, 45 (4), 691-707.

Simhandl, Katrin (2009), 'Beyond boundaries? Comparing the construction of the political categories "Gypsies" and "Roma" before and after EU enlargement', in Nando Sigona and Nidhi Trehan (eds), Romani Politics in Contemporary Europe: Poverty, Ethnic Mobilisation, and the Neoliberal Order, Basingstoke: Palgrave Macmillan, pp. 72-93.

Soysal, Yasmin (1994), Limits of Citizenship: Migrants and Post-National Membership in Europe, Chicago, IL: University of Chicago Press. 
Spivak, Gayatri (1988), 'Can the subaltern speak?', in Cary Nelson and Lawrence Grossberg (eds), Marxism and the Interpretation of Culture, London: Macmillan Education, pp. 271-316.

Stevens, Jacqueline (1999), Reproducing the State, Princeton, NJ: Princeton University Press.

Torpey, John (2000), The Invention of the Passport: Surveillance, Citizenship and the State, Cambridge: Cambridge University Press.

Triandafyllidou, Anna (2001), Immigrants and National Identity in Europe, London: Routledge.

Veres, Judit (2019), 'Dynamics of (un)employment: Welfare experiences in Hungary', ETHOS country report for ETHOS report D5.5, accessed 24 March 2020 at https:// www.ethos-europe.eu/.

Vermeersch, Peter (2012), 'Reframing the Roma: EU initiatives and the politics of reinterpretation', Journal of Ethnic and Migration Studies, 38 (8), 1195-212.

Wimmer, Andreas and Nina Glick Schiller (2002), 'Methodological nationalism and beyond: Nation-state building, migration and the social sciences', Global Networks, 2 (4), 301-34.

Zemandl, Eva (2018), 'The Roma experience of political (in)justice: The case of school (de)segregation in Hungary', ETHOS country report for ETHOS report D5.2, accessed 24 March 2020 at https://www.ethos-europe.eu/. 